\title{
LACK OF RELATIONSHIP BETWEEN MORPHOLOGICAL VARIANCE AND ENZYME HETEROZYGOSITY IN THE PLAICE, PLEURONECTES PLATESSA
}

\author{
B. J. MCANDREW, ${ }^{*}$ R. D. WARD $\dagger$ and J. A. BEARDMORE \\ Department of Genetics, University College of Swansea, Swansea, SA2 8PP, U.K.
}

Received 28.viii.81

\section{SUMMARY}

The hypothesis that enzyme heterozygosity is associated with decreased morphological variance was tested using eight polymorphic loci and three meristic characters in large samples of the plaice, Pleuronectes platessa. The hypothesis was not corroborated and the conclusion drawn that such a relationship although observed by several other workers may not be a general one.

\section{INTRODUCTION}

RELATIONSHIPS between genetical variability and phenotypic variance have received attention from a large number of workers. Older work is well summarised by Lerner (1954) who concluded that genetic homeostasis dependent upon heterozygosity maintains the relative phenotypic uniformity of outbred populations. Inbreeding leads initially to a decrease in phenotypic variance but later to increased variance in many characters (such as those of an anatomical nature) as homozygosity becomes greater. The advent of electrophoretic techniques enabling more objective measures of genetical variability has recently stimulated more work bearing on this question.

Mitton (1978) examined three populations of the fish Fundulus heteroclitus for seven morphological characters and five polymorphic enzyme loci: he found that generally heterozygotes had lower phenotypic variation than homozygotes. Eanes (1978) came to a similar conclusion after examining six polymorphic loci and two morphological traits in the monarch butterfly, Danaus plexippus. In contrast, Handford (1980) found no differences in phenotypic variability (using eleven metric characters) between rufous-collared sparrows, Zonotrichia capensis, homozygous or heterozygous at four enzyme loci. Handford points out that unlike Fundulus and Danaus, Zonotrichia is a homiotherm, and suggests that such associations may be found more readily, or only, in poikilotherms and invertebrates.

It is important that this subject be investigated further. The only way in which heterozygotes at specific enzyme loci could generally be associated with a reduction in morphological variability at the level of the individual would be through developmental interactions with the character in question.

Present addresses: *Institute of Aquaculture, University of Stirling, Stirling; and $\uparrow$ Department of Human Sciences, Loughborough University, Loughborough, Leicestershire, LE11 3TU. 
Such interactions are not reconcilable with a neutral theory for the origin and maintenance of enzyme polymorphisms, and could only be explained through a selectionist model.

We present here a further test of the hypothesis, using three morphological characters and eight polymorphic enzyme loci in large samples of the marine flatfish, Pleuronectes platessa (plaice).

\section{MATERIALS AND METHODS}

Samples of older plaice (1+ year classes) were collected by trawling in the Bristol Channel, 1973-77, and off the Great Orme, Anglesey (NE Irish Sea), 1974 and 1976. O group plaice (fish less than one year old) were collected by pushnetting in shallow water on the sandy beaches of South Wales (1973-77), by far the greatest number coming from Pendine Sands, Carmarthen Bay. These $\mathrm{O}$ group fish and the older Bristol Channel fish are thought to comprise a panmictic and relatively isolated population, with rather little immigration from other Irish Sea or English Channel stocks (Simpson, 1959; Macer, 1972).

Two meristic characters (caudal and anal fin ray numbers, CFR and AFR respectively) were counted for virtually all fish assayed electrophoretically, and a third such character (dorsal fin ray, DFR) on fish collected in the later stages of the project.

Five polymorphic enzyme loci (Pgm-1, Ada, $\alpha$ Gpdh-1, Mdh-2 and $P g i$-2) were assayed from muscle tissue of virtually all fish, and a further three polymorphic loci (Idh-2, $\alpha G p d h-2$ and $S d h)$ from liver tissue of many of the $1+$ (adult) fish. Details of the electrophoretic procedures followed are given in Ward and Beardmore (1977).

Cross-tabulations and some of the statistical tests were performed using the SPSS computer package. Relationships between morphological variation and enzyme variation were analysed in a variety of ways. Firstly, for each locus the morphological variance (CFR, AFR, or DFR) of homozygotes was compared with the morphological variance of heterozygotes by a one-tailed $F$-test $\left(H_{0}: S^{2}\right.$ homozygotes $=S^{2}$ heterozygotes, $H_{1}: S^{2}$ homozygotes $>S^{2}$ heterozygotes). Where heterozygotes were more variable than homozygotes, a two-tailed $F$-test was applied. However, some of the distributions of the morphological characters (particularly CFR) deviate significantly from normality, and could give rise to spuriously high $F$ values (the $F$-test being particularly sensitive to such deviations). In practice, few $F$ values were statistically significant and therefore one is unlikely to commit a type I error and reject a true null hypothesis. Nevertheless, a second and probably more robust test of the null hypothesis was also applied (Levene, 1960). For each morphological variable in either the homozygote or heterozygote category a new variable was constructed, $y_{i}=\left|x_{i}-\bar{x}\right|$ for each case $i$, and the two $\bar{y}$ values (homozygotes and heterozygotes) compared using a $t$-test, one or two-tailed as before. Thirdly, the distributions of fin ray numbers in homozygous and heterozygous individuals were compared using a $2 \times n$ chi-square test. Adjacent classes were pooled where expected numbers were less than five. This test simply compared distributions, not variances. 


\section{Results}

Distributions of CFR, AFR and DFR are given in fig. 1 (for the Bristol Channel $\mathrm{O}$ group fish) and table 1 . It will be seen that many show significant skewness or kurtosis, significance levels being assessed by comparing the observed values with their standard errors (Sokal and Rohlf, 1969). In particular, CFR values are right-skewed and peaked. It should also be noted that distributions differ between samples from the Bristol Channel and the Great Orme. For example, mean DFR count is lower in the Great Orme fish and the CFR mean and variance are higher.

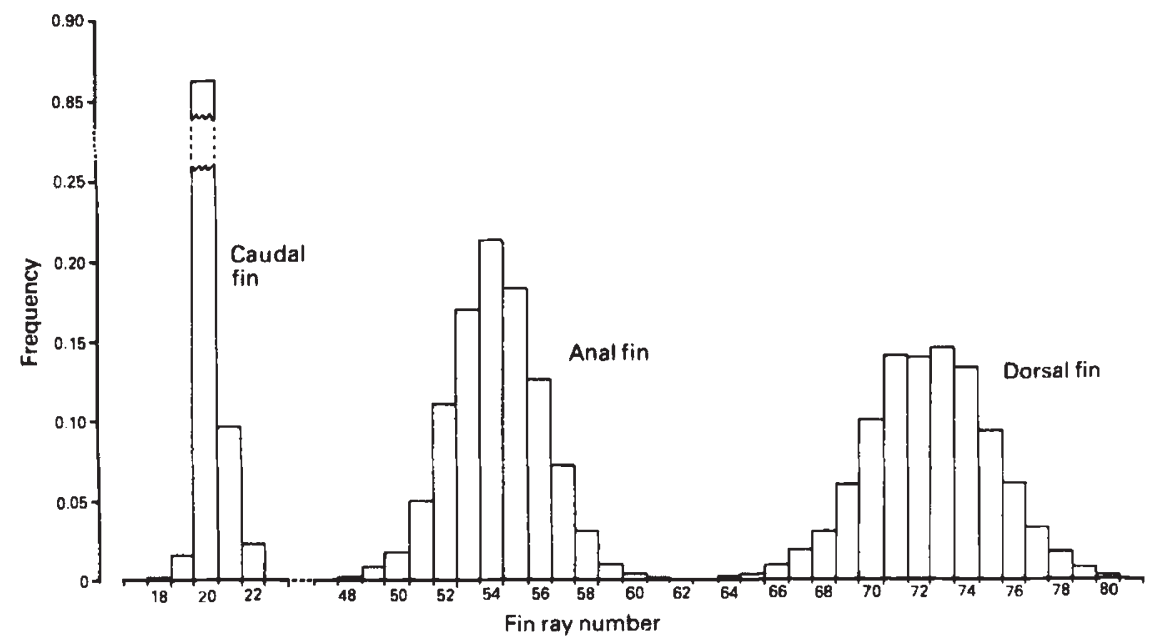

FIG. 1.-Distributions of caudal, anal and dorsal fin ray numbers in Bristol Channel $\mathrm{O}$ group plaice. Note breaks in both axes. AFR and DFR distributions are non-overlapping. Variances and other parameters are presented in table 1.

TABLE 1

Distributions of the morphological characters in adult $(1+)$ group fish

\begin{tabular}{|c|c|c|c|c|c|c|c|}
\hline Population & Fin ray & $N$ & $\bar{x}$ & $S^{2}$ & $C V$ & Skew & Kurtosis \\
\hline $\begin{array}{l}\text { Bristol Channel } \\
\text { O Group }\end{array}$ & $\begin{array}{l}\text { caudal } \\
\text { anal } \\
\text { dorsal }\end{array}$ & $\begin{array}{l}4199 \\
4096 \\
3404\end{array}$ & $\begin{array}{l}20 \cdot 12 \\
54 \cdot 18 \\
72 \cdot 44\end{array}$ & $\begin{array}{l}0.20 \\
3.96 \\
7 \cdot 19\end{array}$ & $\begin{array}{l}2 \cdot 22 \\
3 \cdot 67 \\
3 \cdot 70\end{array}$ & $\begin{array}{l}1 \cdot 71^{* * * *} \\
-0 \cdot 07 \\
-0 \cdot 24^{* * *}\end{array}$ & $\begin{array}{l}8 \cdot 71^{* * *} \\
1 \cdot 03^{* * *} \\
0 \cdot 89^{* * *}\end{array}$ \\
\hline $\begin{array}{l}\text { Bristol Channel } \\
\text { Adults }\end{array}$ & $\begin{array}{l}\text { caudal } \\
\text { anal } \\
\text { dorsal }\end{array}$ & $\begin{array}{l}893 \\
881 \\
486\end{array}$ & $\begin{array}{l}20 \cdot 10 \\
54 \cdot 29 \\
72 \cdot 50\end{array}$ & $\begin{array}{l}0 \cdot 19 \\
3 \cdot 48 \\
6 \cdot 15\end{array}$ & $\begin{array}{l}2 \cdot 16 \\
3.44 \\
3.42\end{array}$ & $\begin{array}{l}1.46^{* * *} \\
-0.01 \\
-0.08\end{array}$ & $\begin{array}{l}8.98^{* * * *} \\
0.51^{* *} \\
0.03\end{array}$ \\
\hline Great Orme & $\begin{array}{l}\text { caudal } \\
\text { anal } \\
\text { dorsal }\end{array}$ & $\begin{array}{l}292 \\
292 \\
149\end{array}$ & $\begin{array}{l}20 \cdot 40 \\
53 \cdot 51 \\
70 \cdot 85\end{array}$ & $\begin{array}{r}0 \cdot 44 \\
3 \cdot 85 \\
10 \cdot 20\end{array}$ & $\begin{array}{l}3 \cdot 25 \\
3.67 \\
4 \cdot 51\end{array}$ & $\begin{aligned} & 1 \cdot 06^{* * * *} \\
-0.25 & -0.27\end{aligned}$ & $\begin{array}{c}1.32^{* * *} \\
0.66^{*} \\
-0.26\end{array}$ \\
\hline
\end{tabular}

Skewness $=\sum((x-\tilde{x}) / S)^{3} / N$. Kurtosis $=\sum((x-\bar{x}) / S)^{4} / N-3$.

Probability levels used throughout this article:

${ }^{*} 0.05>P>0.01$,

${ }^{* *} 0.01>P>0.001$, *** $P<0.001$. 
TABLE 2

Pearson (above diagonal) and Spearman (below diagonal) correlation coefficients for the three fin ray counts

\begin{tabular}{|c|c|c|c|c|c|c|c|c|c|}
\hline & \multicolumn{3}{|c|}{ Combine } & \multicolumn{3}{|c|}{ B. Channel adults } & \multicolumn{3}{|c|}{ Great Orme adults } \\
\hline & CFR & AFR & DFR & CFR & AFR & DFR & CFR & AFR & DFR \\
\hline & & $0.037^{*}$ & $\begin{array}{l}0.038^{*} \\
0.717^{* * *}\end{array}$ & & & $\begin{array}{l}0.005 \\
0.604^{* * *}\end{array}$ & & $-0 \cdot 155^{* *}$ & $\begin{array}{c}-0.173^{*} \\
0.712^{* * *}\end{array}$ \\
\hline & $0 \cdot 040^{*}$ & $0.705^{* *}$ & & 0.048 & $0.675^{* *}$ & & $-0 \cdot 185$ & $0.706^{* * *}$ & \\
\hline
\end{tabular}

Table 2 shows that AFR and DFR counts are highly correlated with one another in all three samples, with correlation coefficients between about 0.6 and $0 \cdot 7$. These two characters are expected to be developmentally related to one another. Correlations between CFR and AFR or DFR are low, and attain statistical significance in the Bristol Channel fish only through the large sample sizes. Interestingly, the correlations are in different directions in the Bristol Channel and Great Orme fish, being positive and negative respectively. The CFR/AFR and CFR/DFR correlations are sufficiently low that CFR can be considered, for practical purposes, to be an independent character. The non-independent nature of AFR and DFR counts should be borne in mind when considering the following results.

Heterozygosities for each locus are generally similar over the three samples. The only significant exception is for Pgi-2, where the Great Orme fish are significantly more heterozygous than the Bristol Channel adults $(P=0 \cdot 019)$. Heterozygosity levels can be assessed from tables 3 and 4 , and allele frequencies for the earlier collections of Bristol Channel (BC) and Great Orme (GO) fish are given in Ward and Beardmore (1977). Genotype frequencies do not deviate from Hardy-Weinberg expectations.

Tables 3 and 4 compare morphological variation in homozygotes and heterozygotes using the three tests outlined earlier. Such tests are clearly at their most powerful when the two classes of genotypes are approximately equally abundant. Thus the most rigorous tests are those involving $P g m-1$ (heterozygosity of BC adults $=0.51$ ), followed by $A d a$ and $\alpha G p d h-2(0.43)$, $I d h-2$ and $S d h(0.59$ and 0.41 respectively), $\alpha G p d h-1(0.24), M d h-2(0.22)$ and finally $P g i-2(0 \cdot 10)$.

Table 3 presents the results of 45 tests $(3$ meristic characters $\times 5$ loci $\times 3$ samples). It can be seen that the results of the $F$ and $t$-tests are in general agreement with one another, $F$ values greater than one generally being associated with positive $t$ values (signifying greater homozygote variability) and $F$ values less than one associated with negative $t$ values. $F$ values greater than one and positive $t$ values were observed in 25 and 21 instances respectively, numbers very close to those expected on a random basis. Homozygotes were significantly more variable than heterozygotes in only two $F$-tests and two $t$-tests, and significantly less variable in three $F$ tests and three $t$-tests. Two of the 45 chi-square tests demonstrated different fin ray distributions between homozygous and heterozygous classes.

Table 4 presents the results of a further nine tests (the three meristic characters $\times 3$ additional loci in the $\mathrm{BC}$ adult population). Six of both the $F$ and $t$-tests show homozygotes to be the more variable, but none of these is statistically significant. The one $t$-test to give a significant result shows heterozygotes to be the more variable. One chi-square test is significant. 
TABLE 3

Tests for differences in the distribution of fin ray numbers between fish homozygous or heterozygous at each of five enzyme loci

\begin{tabular}{|c|c|c|c|c|c|c|c|c|}
\hline Fin & $N$ & Locus & $S^{2} \operatorname{Hom}(n)$ & $\begin{array}{l}\text { Variance ratio test } \\
\qquad S^{2} \operatorname{Het}(n)\end{array}$ & $F$ & $\begin{array}{c}\text { Levene } t \\
t\end{array}$ & $x^{2}$ & $\mathrm{i}$ df \\
\hline $\begin{array}{l}\text { O group } \\
\text { Caudal }\end{array}$ & $\begin{array}{l}\text { ish } \\
4199\end{array}$ & $\begin{array}{l}\text { Pgm } \\
\text { Ada } \\
\alpha G p d h-1 \\
\text { Mdh-2 } \\
\text { Pgi-2 }\end{array}$ & $\begin{array}{l}0 \cdot 197(2189) \\
0 \cdot 206(2422) \\
0 \cdot 206(3223) \\
0 \cdot 207(3294) \\
0 \cdot 203(3691)\end{array}$ & $\begin{array}{l}0.212(2010) \\
0 \cdot 202(1777) \\
0 \cdot 198(976) \\
0 \cdot 194(905) \\
0 \cdot 213(508)\end{array}$ & $\begin{array}{l}0.93 \\
1.02 \\
1.04 \\
1.07 \\
0.95\end{array}$ & $\begin{array}{l}-0.69 \\
+0 \cdot 70 \\
-0.56 \\
+1 \cdot 68^{*} \\
-0.03\end{array}$ & $\begin{array}{l}2 \cdot 85 \\
2 \cdot 04 \\
4 \cdot 63 \\
4 \cdot 02 \\
1 \cdot 44\end{array}$ & $\begin{array}{l}4 \\
4 \\
3 \\
3 \\
3\end{array}$ \\
\hline Anal & 4096 & $\begin{array}{l}\text { Pgm } \\
\text { Ada } \\
\alpha G p d h-1 \\
\text { Mdh-2 } \\
\text { Pgi-2 }\end{array}$ & $\begin{array}{l}3.779(2133) \\
4.045(2365) \\
3.902(3142) \\
3.882(3215) \\
4.000(3600)\end{array}$ & $\begin{array}{l}4 \cdot 161(1963) \\
3 \cdot 851(1731) \\
4 \cdot 155(954) \\
4 \cdot 259(881) \\
3 \cdot 695(496)\end{array}$ & $\begin{array}{l}0.91 \\
1.05 \\
0.94 \\
0.91 \\
1.08\end{array}$ & $\begin{array}{l}-1 \cdot 86 \\
+0 \cdot 32 \\
-1 \cdot 80 \\
-0.81 \\
+0.83\end{array}$ & $\begin{array}{c}24 \cdot 57^{*} \\
6 \cdot 20 \\
14 \cdot 01 \\
12 \cdot 94 \\
8 \cdot 26\end{array}$ & $\begin{array}{l}12 \\
12 \\
11 \\
11 \\
10\end{array}$ \\
\hline Dorsal & 3404 & $\begin{array}{l}\text { Pgm } \\
\text { Ada } \\
\alpha G p d h-1 \\
\text { Mdh-2 } \\
\text { Pgi-2 }\end{array}$ & $\begin{array}{l}7 \cdot 162(1780) \\
7 \cdot 193(1942) \\
7 \cdot 173(2599) \\
7 \cdot 043(2671) \\
7 \cdot 111(2992)\end{array}$ & $\begin{array}{l}7 \cdot 233(1624) \\
7 \cdot 198(1462) \\
7 \cdot 252(805) \\
7 \cdot 746(733) \\
7.787(412)\end{array}$ & $\begin{array}{l}0.99 \\
1.00 \\
0.99 \\
0.91 \\
0.91\end{array}$ & $\begin{array}{l}-0 \cdot 48 \\
-0 \cdot 17 \\
+0 \cdot 15 \\
-0.88 \\
-0 \cdot 10\end{array}$ & $\begin{array}{r}12 \cdot 59 \\
13 \cdot 15 \\
19 \cdot 04 \\
7 \cdot 38 \\
19 \cdot 99\end{array}$ & $\begin{array}{l}16 \\
15 \\
14 \\
14 \\
13\end{array}$ \\
\hline $\begin{array}{l}\text { Bristol C } \\
\text { Caudal }\end{array}$ & $\begin{array}{l}\text { lannel } \\
893\end{array}$ & $\begin{array}{l}\text { dult (1+) fis } \\
\text { Pgm } \\
\text { Ada } \\
\alpha G p d h-1 \\
\text { Mdh-2 } \\
\text { Pgi-2 }\end{array}$ & $\begin{array}{l}0 \cdot 201(439) \\
0 \cdot 224(500) \\
0 \cdot 183(676) \\
0 \cdot 181(700) \\
0 \cdot 183(803)\end{array}$ & $\begin{array}{l}0 \cdot 178(454) \\
0 \cdot 148(370) \\
0 \cdot 205(217) \\
0 \cdot 215(193) \\
0 \cdot 245(90)\end{array}$ & $\begin{array}{l}1.13 \\
1.51^{* * *} \\
0.89 \\
0.84 \\
0.75\end{array}$ & $\begin{array}{l}+0.32 \\
+3.77^{* * *} \\
-2.81^{* *} \\
-2.42^{*} \\
+0.94\end{array}$ & $\begin{array}{l}0 \cdot 40 \\
7 \cdot 37 \\
8 \cdot 67^{*} \\
2 \cdot 39 \\
0 \cdot 81\end{array}$ & $\begin{array}{l}3 \\
3 \\
2 \\
2 \\
1\end{array}$ \\
\hline Anal & 881 & $\begin{array}{l}\text { Pgm } \\
\text { Ada } \\
\alpha G d h-1 \\
\text { Mdh-2 } \\
\text { Pgi-2 }\end{array}$ & $\begin{array}{l}3 \cdot 805(433) \\
3.492(494) \\
3.614(664) \\
3 \cdot 647(690) \\
3.587(791)\end{array}$ & $\begin{array}{l}3.495(448) \\
3.466(368) \\
3.775(217) \\
3.663(191) \\
4.288(90)\end{array}$ & $\begin{array}{l}1 \cdot 08 \\
1 \cdot 01 \\
0.95 \\
1 \cdot 00 \\
0.84\end{array}$ & $\begin{array}{l}-0 \cdot 61 \\
+0 \cdot 34 \\
-0 \cdot 31 \\
+0 \cdot 29 \\
-1 \cdot 39\end{array}$ & $\begin{array}{r}6 \cdot 94 \\
15 \cdot 27 \\
8 \cdot 48 \\
6 \cdot 87 \\
7 \cdot 15\end{array}$ & $\begin{array}{l}9 \\
9 \\
8 \\
7 \\
7\end{array}$ \\
\hline Dorsal & 486 & $\begin{array}{l}\text { Pgm } \\
\text { Ada } \\
\alpha G p d h-1 \\
\text { Mdh-2 } \\
\text { Pgi-2 }\end{array}$ & $\begin{array}{l}5 \cdot 674(237) \\
6 \cdot 770(282) \\
6 \cdot 305(367) \\
6 \cdot 203(381) \\
5 \cdot 881(445)\end{array}$ & $\begin{array}{l}6 \cdot 579(249) \\
5 \cdot 325(204) \\
5 \cdot 663(119) \\
6 \cdot 021(105) \\
9 \cdot 288(41)\end{array}$ & $\begin{array}{l}0 \cdot 86 \\
1 \cdot 27^{*} \\
1 \cdot 11 \\
1 \cdot 03 \\
0.63^{*}\end{array}$ & $\begin{array}{l}-1 \cdot 26 \\
+1 \cdot 27 \\
+0 \cdot 90 \\
+0 \cdot 11 \\
-2 \cdot 73^{* *}\end{array}$ & $\begin{array}{r}7 \cdot 23 \\
15 \cdot 28 \\
6 \cdot 87 \\
8 \cdot 39 \\
10 \cdot 68\end{array}$ & $\begin{array}{r}11 \\
11 \\
9 \\
9 \\
7\end{array}$ \\
\hline $\begin{array}{l}\text { Great Or } \\
\text { Caudal }\end{array}$ & $\begin{array}{l}\text { ne adul } \\
292\end{array}$ & $\begin{array}{l}\text { (1+) fish } \\
\text { Pgm } \\
\text { Ada } \\
\alpha G p d h-1 \\
\text { Mdh-2 } \\
\text { Pgi-2 }\end{array}$ & $\begin{array}{l}0.428(150) \\
0.375(170) \\
0.432(217) \\
0.454(228) \\
0.395(248)\end{array}$ & $\begin{array}{l}0.455(142) \\
0.530(122) \\
0.466(75) \\
0.393(64) \\
0.702(44)\end{array}$ & $\begin{array}{l}0.94 \\
0 \cdot 71^{*} \\
0.93 \\
1 \cdot 16 \\
0.56^{*}\end{array}$ & $\begin{array}{l}-0.67 \\
-0.84 \\
-0.92 \\
-0.67 \\
-0.73\end{array}$ & $\begin{array}{l}1.39 \\
1.61 \\
0.86 \\
2.89 \\
1.89\end{array}$ & $\begin{array}{l}2 \\
2 \\
2 \\
2 \\
2\end{array}$ \\
\hline Anal & 292 & $\begin{array}{l}\text { Pgm } \\
\text { Ada } \\
\alpha G p d h-1 \\
\text { Mdh-2 } \\
\text { Pgi-2 }\end{array}$ & $\begin{array}{l}4 \cdot 279(150) \\
4 \cdot 165(170) \\
3 \cdot 846(217) \\
3.987(228) \\
3 \cdot 870(248)\end{array}$ & $\begin{array}{l}3 \cdot 389(142) \\
3 \cdot 385(122) \\
3 \cdot 731(75) \\
3 \cdot 234(64) \\
3 \cdot 772(44)\end{array}$ & $\begin{array}{l}1 \cdot 26 \\
1 \cdot 23 \\
1 \cdot 03 \\
1 \cdot 23 \\
1 \cdot 03\end{array}$ & $\begin{array}{l}+1.06 \\
+1.41 \\
-0.06 \\
+1.21 \\
+0.37\end{array}$ & $\begin{array}{r}12 \cdot 10 \\
7 \cdot 60 \\
8 \cdot 80 \\
4 \cdot 88 \\
5 \cdot 66\end{array}$ & $\begin{array}{l}7 \\
7 \\
6 \\
5 \\
5\end{array}$ \\
\hline Dorsal & 149 & $\begin{array}{l}\text { Pgm } \\
\text { Ada } \\
\alpha G p d h-1 \\
M d h-2 \\
\text { Pgi-2 }\end{array}$ & $\begin{array}{l}10 \cdot 486(79) \\
10 \cdot 015(86) \\
10 \cdot 642(106) \\
10 \cdot 924(114) \\
10 \cdot 519(126)\end{array}$ & $\begin{array}{r}9 \cdot 666(70) \\
10 \cdot 604(63) \\
8 \cdot 873(43) \\
8 \cdot 059(35) \\
8 \cdot 846(23)\end{array}$ & $\begin{array}{l}1.08 \\
0.94 \\
1 \cdot 20 \\
1.36 \\
1.19\end{array}$ & $\begin{array}{l}+0.11 \\
-0.07 \\
+0.52 \\
+1.41 \\
+1.12\end{array}$ & $\begin{array}{r}13.51 \\
3.64 \\
5.93 \\
2.05 \\
7.53\end{array}$ & $\begin{array}{r}9 \\
10 \\
5 \\
4 \\
3\end{array}$ \\
\hline
\end{tabular}

An $F$ value greater than 1 or positive $t$ value indicates that homozygotes are morphologically more variable than heterozygotes: see text for further explanation. $\mathrm{Ada}^{+}$and $\mathrm{Ada}^{++}$: technical difficulties prevented this locus from being typed in all fish. 
TABLE 4

Tests for differences in the distribution of fin ray numbers between fish homozygous or heterozygous at each of three further enzyme loci-Bristol Channel adult $(1+)$ fish only

\begin{tabular}{|c|c|c|c|c|c|c|c|c|}
\hline & & & \multicolumn{3}{|c|}{ Variance ratio test } & Levene $t$ & \multicolumn{2}{|c|}{ Chi } \\
\hline Fin & $N$ & Locus & $s^{2} \operatorname{Hom}(n)$ & $S^{2} \operatorname{Het}(n)$ & $F$ & $t$ & $x^{2}$ & df \\
\hline Caudal & $\begin{array}{l}737 \\
671 \\
290\end{array}$ & $\begin{array}{l}I d h-2 \\
\alpha G p d h-2 \\
S d h\end{array}$ & $\begin{array}{l}0 \cdot 201(302) \\
0.210(361) \\
0 \cdot 225(172)\end{array}$ & $\begin{array}{l}0 \cdot 189(435) \\
0 \cdot 177(310) \\
0 \cdot 290(118)\end{array}$ & $\begin{array}{l}1.06 \\
1 \cdot 19 \\
0.78\end{array}$ & $\begin{array}{l}+1.45 \\
+1.61 \\
-2.56^{*}\end{array}$ & $\begin{array}{l}1.91 \\
1.89 \\
2.63\end{array}$ & $\begin{array}{l}3 \\
3 \\
2\end{array}$ \\
\hline Anal & $\begin{array}{l}728 \\
666 \\
285\end{array}$ & $\begin{array}{l}I d h-2 \\
\alpha G p d h-2 \\
S d h\end{array}$ & $\begin{array}{l}3 \cdot 832(299) \\
3 \cdot 583(359) \\
3 \cdot 705(169)\end{array}$ & $\begin{array}{l}3.398(429) \\
3.694(307) \\
3.742(116)\end{array}$ & $\begin{array}{l}1.13 \\
0.97 \\
0.99\end{array}$ & $\begin{array}{l}+0.55 \\
-0.26 \\
-0.24\end{array}$ & $\begin{array}{l}5 \cdot 74 \\
7 \cdot 35 \\
1.62\end{array}$ & $\begin{array}{l}9 \\
9 \\
7\end{array}$ \\
\hline Dorsal & $\begin{array}{r}486 \\
486 \\
91\end{array}$ & $\begin{array}{l}I d h-2 \\
\alpha G p d h-2 \\
S d h\end{array}$ & $\begin{array}{l}6.919(195) \\
6.208(262) \\
6.992(54)\end{array}$ & $\begin{array}{l}5 \cdot 656(291) \\
6 \cdot 100(224) \\
5 \cdot 201(37)\end{array}$ & $\begin{array}{l}1 \cdot 22 \\
1.02 \\
1 \cdot 34\end{array}$ & $\begin{array}{l}+1.02 \\
+0.21 \\
+0.80\end{array}$ & $\begin{array}{c}21.61^{*} \\
3.92 \\
6.60\end{array}$ & $\begin{array}{r}11 \\
10 \\
5\end{array}$ \\
\hline
\end{tabular}

The general conclusion from these results must be that there is no evidence from this material to support the hypothesis that homozygotes are significantly more variable morphologically than heterozygotes. It may be argued that the three fish samples analysed here are each rather heterogeneous. For example, the $\mathrm{O}$ group and $\mathrm{BC} 1+$ group fish came from collections made between 1973 and 1977. The $1+$ fish are also composed of different age classes. However, we have no reason to suppose that such aggregation conceals any real associations. The four sets of $O$ group fish $(1973,1974,1975$ and 1977) were assessed separately by each of the three tests, but the same general picture of small and random associations emerged.

Another way of examining relationships between morphological variability and genetic heterozygosity is to look at multi-locus heterozygosity. Since virtually all fish were typed at the five loci Pgm-1, Ada, $\alpha$ Gpdh-1, $M d h-2$ and $P g i-2$, each fish can be assigned a heterozygosity score ranging from 0 (all five loci homozygous) to 5 (all heterozygous). The variance for each meristic character for each of the five genetic classes can then be assessed. If heterozygosity were associated with a reduction in morphological variability, then one might expect to see a progressive decrease in variance as multi-locus heterozygosity increases. There are no consistent indications of such a trend (fig. 2 and table 5).

\section{Discussion}

The distributions of three meristic characters in the plaice (two of which are highly correlated) are independent of homozygosity or heterozygosity at five to eight enzyme loci. The hypothesis that heterozygotes should, in general, show reduced morphological variance in comparison with homozygotes is thus not supported. These findings agree with those of Handford (1980) for the bird Zonotrichia capensis, but contrast with the results of Mitton (1978) for the fish Fundulus heteroclitus and Eanes (1978) for the butterfly Danaus plexippus. The results of the latter two authors were consistent with the hypothesis. Eanes (1981) has commented that Handford's data set was too small to test the hypothesis realistically: such a criticism cannot be levelled at our data. 

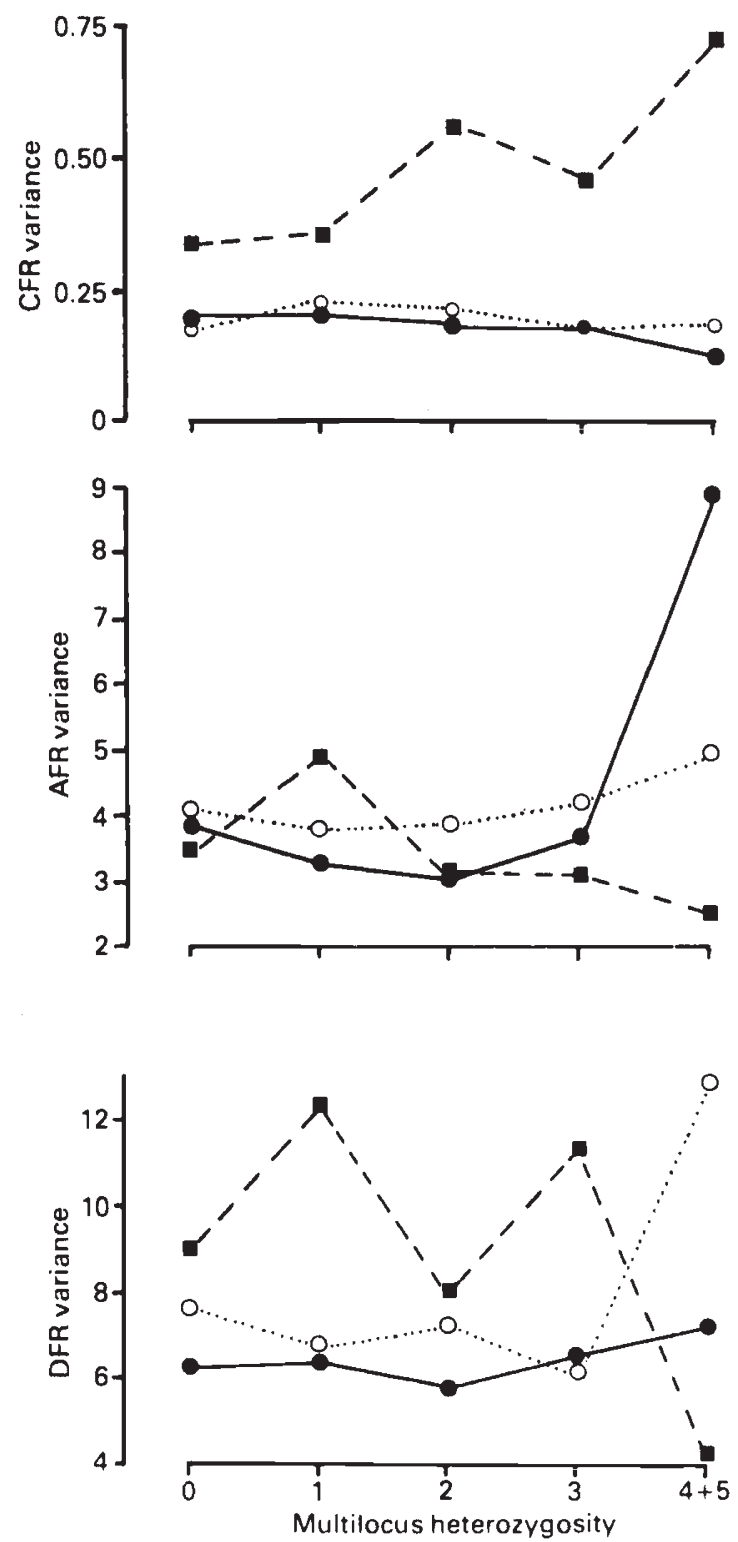

FIG. 2.-Fin ray variances plotted against multilocus heterozygosity classes. $\bigcirc \cdots \cdots=$ Bristol Channel $\mathrm{O}$ group fish; $-\mathrm{O}=$ Bristol Channel $1+$ group fish; $---\mathbf{D}=$ Great Orme 1+ fish. Samples sizes are given in table 5. See text for further explanation.

It is not easy to account for these varying results, although experimental designs and methods and analysis differ between studies, making direct comparisons difficult. Mitton studied seven meristic characters and five polymorphic enzymes, Handford eleven metric characters and four enzymes. Their sample sizes were small compared with the present study. 
TABLE 5

Sample sizes for the data presented in fig. 2

\begin{tabular}{|c|c|c|c|c|c|c|c|}
\hline \multirow[b]{2}{*}{ Fin } & \multirow[b]{2}{*}{ Sample } & \multicolumn{5}{|c|}{ Multilocus heterozygosity class } & \multirow[b]{2}{*}{ Total } \\
\hline & & 0 & 1 & 2 & 3 & $4 \& 5$ & \\
\hline CFR & $\begin{array}{l}\text { O group } \\
\text { BC } 1+ \\
\text { GO } 1+\end{array}$ & $\begin{array}{r}652 \\
120 \\
41\end{array}$ & $\begin{array}{r}1634 \\
339 \\
113\end{array}$ & $\begin{array}{r}1303 \\
290 \\
92\end{array}$ & $\begin{array}{r}509 \\
99 \\
36\end{array}$ & $\begin{array}{r}101 \\
22 \\
10\end{array}$ & $\begin{array}{r}4199 \\
870 \\
292\end{array}$ \\
\hline AFR & $\begin{array}{l}\text { O group } \\
\text { BC 1+ } \\
\text { GO } 1+\end{array}$ & $\begin{array}{r}634 \\
116 \\
41\end{array}$ & $\begin{array}{r}1594 \\
337 \\
113\end{array}$ & $\begin{array}{r}1276 \\
289 \\
92\end{array}$ & $\begin{array}{r}493 \\
98 \\
36\end{array}$ & $\begin{array}{l}99 \\
22 \\
10\end{array}$ & $\begin{array}{r}4096 \\
862 \\
292\end{array}$ \\
\hline DFR & $\begin{array}{l}\text { O group } \\
\text { BC 1+ } \\
\text { GO } 1+\end{array}$ & $\begin{array}{r}514 \\
68 \\
21\end{array}$ & $\begin{array}{r}1339 \\
197 \\
59\end{array}$ & $\begin{array}{r}1044 \\
158 \\
40\end{array}$ & $\begin{array}{r}422 \\
47 \\
22\end{array}$ & $\begin{array}{r}85 \\
16 \\
7\end{array}$ & $\begin{array}{r}3404 \\
486 \\
149\end{array}$ \\
\hline
\end{tabular}

Eanes measured two metric characters and about 1300 individuals were assayed at each of six loci. Both Eanes and Mitton found it difficult to account for their finding that enzyme heterozygotes are more variable morphologically than homozygotes; in particular they found it surprising that such effects should be observed when only five or six loci were screened out of the thousands expected to be polymorphic. Handford suggested that the reason he failed to find any associations may be because he was examining a homiotherm, and that any such associations may be more striking in invertebrates and poikilotherms. The present study shows that the hypothesis may not, in fact, hold generally even for poikilotherms.

Another relevant study is that of Beardmore and Shami (1979), working on experimental populations of the guppy, Poecilia reticulata. They demonstrated the action of very strong stabilising selection for caudal fin ray number, and further found that the central (optimal) CFR phenotypes were significantly more heterozygous (over four enzyme loci) than more extreme phenotypes. Central fin ray phenotypes in the plaice are no more heterozygous than extreme phenotypes, but older age classes show little reduction in morphological variance. This implies that stabilising selection for CFR, AFR and DFR counts in plaice is weak or absent, at least over the age range analysed. (Very young $O$ group fish, of lengths less than $2 \mathrm{~cm}$, were not assayed.) We might then speculate that where stabilising selection can be shown to operate on a quantitative character, an association between heterozygosity and phenotypic variation in that character is more likely to be found than in cases where no stabilising selection is demonstrable. Unfortunately we do not know whether stabilising selection was operating on the quantitative characters assayed by Mitton (1978), Eanes (1978) or Handford (1980).

Clearly many more studies are required before any general conclusions can be drawn concerning relationships between enzyme heterozygosity and morphological variability. The data presented here are clearly consistent with the expectations of neutrality theory, but do not, of course, refute selectionist theory. 


\section{REFERENCES}

BEARDMORE, J. A., AND SHAMI, S. A. 1979. Heterozygosity and the optimum phenotype under stabilising selection. Aquilo Ser. Zool., 20, 100-110.

EANES, W. F. 1978. Morphological variance and enzyme heterozygosity in the monarch butterfly. Nature, 276, 263-264.

EANES, W. F. 1981. Enzyme heterozygosity and morphological variance. Nature, 300, 609610.

HANDFORD, P. 1980. Heterozygosity at enzyme loci and morphological variation. Nature, $286,261-262$.

LERNER, I. M. 1954. Genetic Homeostasis. Oliver and Boyd, Edinburgh.

LEVENE, H. 1960. Robust tests for equality of variances. In Contributions to Probability and Statistics, eds. I. Olkin, S. G. Ghurye, W. Hoeffding, W. G. Madow and H. B. Mann. pp. 278-292. Stanford University Press, Stanford.

MACER, C. T. 1972. The movements of tagged adult plaice in the Irish Sea. Fishery Invest., Lond., Ser. 2. 27 (6), 41 pp.

MITTON, J. B. 1978. Relationship between heterozygosity for enzyme loci and variation of morphological characters in natural populations. Nature, 273, 661-662.

SIMPSON, A. C. 1959. The spawning of plaice (Pleuronectes platessa) in the Irish Sea. Fishery Invest., Lond., Ser. 2. $22(8), 30$ pp.

SOKAL, R. R., AND ROHLF, F. J. 1969. Biometry, Freeman, San Francisco,

WARD, R. D., AND BEARDMORE, J. A. 1977. Protein variation in the plaice, Pleuronectes platessa L. Genet. Res., 30, 45-62. 